\title{
Biogenic and abiogenic low-Mg calcite (bLMC and aLMC): Evaluation of seawater-REE composition, water masses and carbonate diagenesis
}

\author{
'Department of Earth Sciences, Memorial University of Newfoundland, Stjohn's, NL, Canada AlB $3 X 5$ \\ b Department of Earth Sciences, Brock University, St Catharines, ON, Canada US 3A1 \\ - Department of Earth and Atmospheric Sciences, University of Alberta, Edmonton, AB, Canada T6G 2£3 \\ Centre of Coastal Studies, University of New BrunswicfSaint john, NB, Canada E2L 4!5 \\ 'Institute of Paleobiology, Polish Academy of Sciences, uL Twarda 51/55, 00-818 Warszawa, Poland
}

Karem Azmy a,*, Uwe Brand b, Paul Sylvester a, Sara A Gleeson c, Alan Logan ct, Maria Aleksandra Bitner e

\section{ARTICLE INFO}

\section{Article history:}

Received 28 September 2009

Received in revised form 22 October 2010

Accepted 4 November 2010

Available online 11 November 2010

Editor: J.D. Blum

\section{Keywords:}

Biogenic low-Mg calcite (brachiopods)

Burial calcite cements

IREE, REESN seawater compositions

Diagenetic IREE and REEsN variations

\begin{abstract}
The l;REE and shale-normalized (PAAS) REEsN values of modern brachiopods (biogenic low-Mg calcite: blMC) represented by several species from high- to low latitudes, from shallow- to deep waters and from warm- and cold-water environments, define three distinct average 'seawater' trends. The warm- and cold-water brachiopods define two indistinguishable $(\mathrm{p}<0.0 \mathrm{SO})$ groups that mimic open -ocean seawater REE chemistry, exhibiting the typical LREE enrichment with a slightly positive to negative Ce anomaly followed by an otherwise invariant series. Other recent brachiopods from an essentially siliciclastic seabed environment are distinct in both l;REE and REEsN trends from the previous two populations, showing a slight enrichment in the MREEs and an increasing trend in the HREEs. Other groups of modern brachiopods are characterized by elevated REEsN trends relative to the 'normal'groups as well as by complexity of the series trends. The most characteristic feature is the decrease in the HREEs in these brachiopods from areas of unusual productivity (i.e., such as upwelling currents, fluvial input and aerosol dust deposition). Preserved brachiopods from the Eocene and Silurian exhibit REEsN trends and Ce anomalies similar to that of the 'open-ocean' modern brachiopods, although, their enriched l;REE concentrations suggest precipitation ofblMC influenced by extrinsic environmental conditions.

Preservation of the bLMC was tested by comparing the l;REE and REEsN trends of preserved Eocene brachiopods to those of Oligocene brachiopods that were altered in an open diagenetic system in the presence of phreatic meteoric-water. The altered blMC is enriched by approximately one order of magnitude in both l;REE and REEsN trends relative to that in blMC of their preserved counterparts. Similarly, the l;REE and REEsN of preserved Silurian brachiopod blMC were compared to those of their enclosing altered lime mudstone, which exhibits features of partly closed system, phreatic meteoric-water diagenesis. Despite these differences in the diagenetic alteration systems and processes, the l;REEs and REEsN trends of the blMC of altered brachiopods and of originally mixed mineralogy lime mudstones (now diagenetic low-Mg caldte) are enriched by about one order of magnitude relative to those observed in the coeval and preserved blMC.

In contrast to the changes in l;REE and REESN of carbonates exposed to phreatic meteoric-water diagenesis, are the REE compositions oflate burial calcite cements precipitated in diagenetically open systems from burial fluids. The l;REE and REEsN trends of the burial cements mimic those of their host lime mudstone, with all showing slight LREE enrichment and slight HREE depletion, exhibiting a 'chevron' pattern of the REEsN trends. The overall enrichment or depletion of the cement REEsN trends relative to that of their respective host rock material reflects not only the openness of the diagenetic system, but also strong differences in the elemental and REE compositions of the burial fluids. Evaluation of the $(\mathrm{Ce} / \mathrm{Ce} *) \mathrm{sN}$ and $\mathrm{La}=(\mathrm{Pr} / \mathrm{Pr} *) \mathrm{sN}$ anomalies suggests precipitation of the burial calcite cements essentially in equilibrium with their source fluids.
\end{abstract}

2010 Elsevier B.V. All rights reserved.

\section{Introduction}

Modern brachiopods (biogenic low-Mg calcite: bl.MC), representing numerous species, from low to high latitudes and covering the oceans

\footnotetext{
* Corresponding author.

E-mail address: kazmy@mun.ca (K. Azmy).
}

from 2 to $3940 \mathrm{~m}$ depths (Brand et al., 2003; Appendix 1) were evaluated for their potential as proxies of seawater REE composition, water masses and oceanographic processes.These organisms have been overlooked by researchers, who concentrated on studying the distribution ofREE's in other abiogenic and other biogenic components. Among the commonly studied materials are foraminiferas (Palmer, 1985), corals (Scherer and Seitz, 1980; Sholkovitz and Shen, 1995), other carbonate allochems (e.g., Nothdurft et al., 2004), conodonts (e.g., 
Wright et al., 1987), fish teeth (Grandjean et al., 1987), reptile teeth (Picard et al., 2002), phosphate (Bau et al., 1996), chert (Murray et al., 1992), and reefal microbialites (Webb and Kamber, 2000). However, to some degree all of these potential proxies suffer from problems that complicate their REE signals and thus the subsequent interpretation of the seawater composition and other oceanographic processes (Webb and Kamber, 2000; Bright et al., 2009). The foremost concern is the loss and/or overprinting of original REE's trends and compositions due to scavenging processes at or near the sediment pore-water interface (e.g., Banner et al., 1988; Webb et al., 2009) or contamination by terrigenous detritus (Webb and Kamber, 2000; Negrel et al., 2006). Of all these concerns, diagenesis was not considered a major problem because the REE content and distribution remained apparently relatively stable and uniform unless carbonates were subjected to alteration in extremely high water/rock ratio systems (e.g., Banner et al., 1988; Webb et al., 2009), although Shaw and Wasserburg (1985) based on increased REE concentrationssuggested that limestones may be diagenetically altered.

This study is a comprehensive evaluation of brachiopod bLMC mineralogy that is relatively resistant to diagenetic alteration (Brand and Veizer, 1980; Azmy et al, 1998), but its effects can be clearly characterized by available screening methods such as: visual inspection, petrography, luminescence, microstructures, trace elements and stable isotopes (Brand and Veizer, 1980; Brand et al., 2010). In addition, the evaluation of whole rock material (e.g., lime mudstone) and burial calcite cement (aLMC) should provide further insight into diagenetic systems and processes, and impacts on REE distributions. Thus, it should be possible to discern bLMC and aLMC with primary chemical signatures reflective of the ambient and coeval seawater composition, which should also apply to their REE contents, and comparisons with and of altered material should give a good indication of any REE diagenetic re-distribution with meteoric water and burial fluid.

Individual REEs have relatively short residence times, on the order of several hundred years (Alibo and Nozaki, 1999), which is fast compared to the much longer mixing rates of the oceanic water masses (e.g., Broecker and Peng, 1982; Holland, 1984). The oceanic REE composition is a reflection of several exogenic processes, among them mid-ocean ridge hydrothermal circulation, atmospheric/volcanic dust deposition, precipitation/adsorption processes, and input from river water (e.g., Holser, 1997). REEs are a group of fifteen trivalent elements ( $\mathrm{La}$ to $\mathrm{Lu}$ ) with chemical characteristics that change systematically along the series, and in seawater this lanthanide contraction leads to preferential absorption of the light REEs (LREE) relative to the medium (MREE) and heavy REEs (HREE; Sholkovitz and Shen, 1995). Their incorporation into calcite (bLMC and aLMC) falls within a relatively narrow range of partition coefficient values (Zhong and Mucci, 1995), and thus observed variation in the series is a reflection of natural oceanographic and other processes. One of these processes, oxidation, controls the conversion of Ce (III) to Ce(IV) in seawater (Sholkovitz et al., 1994), and the distribution of Eu in seawater is controlled by the same process.

The establishment of a reliable seawater/sedimentary REE proxy is an important consideration because it may provide some crucial information about the secular evolution of the Earth's exogenic system; such as continental weathering, tectonic processes, and oceanographic parameters. Some of the oceanographic features identified in REEs are their close affinity to upwelling (productivity), water depth, stratification, circulation, dust deposition (shallow water fertilization) and continental fluvial run-off with consequently increased productivity (e.g., Shaw and Wasserburg, 1985; Shen and Sanford, 1989; Elderfield et al., 1990; Sholkovitz et al., 1994; Sholkovitz and Shen, 1995; Nothdurft et al., 2004). In addition, the ideal proxy of seawater REEs must be resistant to diagenetic effects, incorporate the REE into its mineral structure in proportion with that in the ambient seawater and at sufficient concentration levels, and their shale-normalized patterns should mimic that of the original ambient seawater (cf. Webb and Kamber, 2000 ).

Modern brachiopods will be used to establish baseline parameters ofREE incorporation into bLMC represented by specimens from warm and cold-water environments. By utilizing specimens from several distinct localities, we should be able to characterize the influences of specific oceanographic processes such as upwelling, and other natural processes such as aerosol dust deposition, riverine flux, coastal settings under siliciclastic deposition on their REE compositions. The application of brachiopod bLMC as a REE proxy for fossil counterparts will be evaluated using a suite of preserved and altered Eocene/ Oligocene ones, and a coeval set of well-preserved Silurian brachiopods and their enclosing lime mudstone. Furthermore, extreme diagenesis will be evaluated with a suite of Ordovician carbonate sediments and cements that have undergone different degrees and stages of diagenetic alteration/precipitation in/from both meteoric water and burial fluid.

\section{Methodology}

\subsection{Sample material}

This study involves modern (Brand et al., 2003), well-preserved Eocene (part of a marine invertebrate collection, which includes aragonitic molluscs from Seymour Island; cf. Ivany et al., 2008 ) and Silurian brachiopods (Azmy et al., 1998 ), representing the primary marine calcite suite (Appendix 1). The study also investigates the REE composition of altered brachiopods from the Oligocene of the Antarctic, altered lime mudstone coeval with the Silurian brachiopods, and a suite of altered Ordovician lime mudstone and deep burial calcite cements from the St. George Group carbonates of western Newfoundland (Azmy et al., 2008, 2009; Appendix 1). The diagenetic state of most brachiopod and whole rock/cement samples (except for the Eocene/Oligocene ones) was petrographically and geochemically investigated by Azmy et al. (1998, 2008, 2009).

Shells of many modern species, recently dead or alive, were collected from different water masses of different temperatures and depths from a wide range oflocalities (Appendix 1; Brand et al., 2003 ). In modern calcitic brachiopods, the periostracum covers the few micrometer thick granular-calcitic primary layer and in turn an inner secondary layer that is composed of fibrous calcite; occasionally a tertiary layer is present in some species. The fibrous layer is normally secreted as low-Mg calcite (cf. Brand et al., 2003 ). In fossil brachiopods, the outer layer (periostracum) is usually absent because of rapid organic decay after the death of the organism. The primary layer may be seen in preserved shells but is easily peeled off when the shells are separated from their host rock. The analyzed brachiopod material was based on the preserved fibrous secondary layer of the calcitic shells (Azmy et al., 1998; Brand et al., 2003). The temperature of the ambient water of modern brachiopods was supplied by Brand et al. (2003), whereas those of the fossil brachiopods are estimates based on previous geochemical studies (Azmy et al., 1998; Came et al., 2007; Ivany et al., 2008).

\subsection{Analytical techniques}

To facilitate analysis, the lime mudstone and calcite cement samples were microdrilled from rock slabs. The cement samples were extracted from crystals, which had their temperatures of precipitation (Th, homogenization temperature of their entrapped primary twophase fluid inclusions) established by microthermometric analysis (Appendix 2; Azmy et al., 2009).

About $5 \mathrm{mg}$ of sample powder (new material) of each sample was digested in $0.2 \mathrm{M} \mathrm{HNO}_{3}$ for $70-80 \mathrm{~min}$ and analyzed by standard addition techniq ues for major (e.g., Ca, Mg), minor (e.g., Sr, Mn), and REE (Coleman et al., 1989) using a Perkin Elmer Sciex "Elan DROf' ICP-MS at 
Memorial University of Newfoundland. Elemental (Ca, Mg, Sr, Na, Mn and $\mathrm{Fe}$ ) analyses of modern and Eocene/Oligocene brachiopods were conducted at Brock University following well-established procedures (cf. Brand et al., 2003). This includes the routine leaching of shell fragments with $10 \%$ HCL to remove adhering and adsorbed foreign matter (e.g., detritus, whole rock) that may otherwise adversely affect their chemistry including REE compositions.

The relative uncertainties (accuracy and precision) of these (AAS and ICP-MS) measurements are better than 5\% (cf. Brand, 2004; Azmy et al., 2009). Normalization of REE concentrations is based on PAAS values (Post-Archean Australian Shale, McLennan, 1989), and CesN ((Ce/Ce*)sN=CesN/(O.SLasN+O.SPrsN)] and LasN ((Pr/Pr*)sN= PrsN/O.SCesN + O.SNdsN)] anomalies were calculated with the equations of Bau and Dulski (1996), and all results are in Appendix 2.

\section{Sample preservation}

Petrographic and geochemical preservation of the modern and Silurian brachiopod shells, subsets utilized in the current study, have been discussed by Brand et al. (2003) and Azmy et al. (1998), respectively. Examination of thin sections shows that the secondary layer fibers (the basic study material) of the investigated modern and fossil shells are clear carbonates and show no clay inclusions. Furthermore, all shell fragments (modern and fossil) are routinely leached with $10 \%$ HCL prior to powdering to remove any extraneous material attached to the bLMC, and the cleaning step result is consistent with measured $\mathrm{AI}$ and $\mathrm{Si}$ concentrations, which are generally below the method detection limit of SO ppb (Azmy et al., 1998 ). Also, all of the investigated Silurian brachiopod shells were collected from shallow marine reef-carbonate deposits, which were protected from siliciclastic influx (Copper and Brunton, 1991; Copper, 1995; Azmy et al., 1998) and thus detrital influence on their REE contents would be minimal to none (e.g., Grandjean et al., 1987; Lecuyer et al., 2004). Microstructures of the Eocene (Fig. 1A) and Silurian brachiopods (Fig. 1C, D) were examined by SEM, which depicts outstanding morphological preservation of the calcite fibers in their secondary shell layer as well as an absence of adhering foreign detritus. In contrast, the internal architecture of the Oligocene brachiopods is replaced by coarse and massive calcite and increased porosity (Fig. 1B), all indicative of extensive diagenetic alteration (cf. Brand, 2004). The microstructural observations of both preservation and alteration in specimens are consistent with their elemental contents (e.g., $\mathrm{Sr}$ and $\mathrm{Mn}$ ) and isotopic compositions (cPC, $8^{18} \mathrm{O}$; Appendix 2).

$\mathrm{Sr}, \mathrm{Mn}, 0^{13} \mathrm{C}$ and $8^{18} \mathrm{O}$ of bLMC are sensitive tracers of diagenetic alteration (Veizer, 1983; Brand, 2004) documented by consistently higher Mn contents, lower Sr contents and more negative values of the stable isotopes in the diagenetic products relative to unaltered counterparts (cf. Brand and Veizer, 1980, 1981). The Sr (935 to $1309 \mathrm{ppm}$ ) and $\mathrm{Mn}$ (16 to $35 \mathrm{ppm}$ ) contents of the presumed preserved Eocene and Silurian shell bLMC (Fig. 2) are similar to those of their modern counterparts (Sr: 450 to 1533 ppm, Mn: 4 to 67 ppm [with one exclusion], Appendix 2; Brand et al., 2003). In contrast, the brachiopods from the Oligocene not only have disrupted internal structures indicative of diagenesis, their Sr (119 to $128 \mathrm{ppm}$ ) and $\mathrm{Mn}$ (5085 to $5849 \mathrm{ppm}$ ) contents are depleted/enriched, respectively, to that of modern and Eocene counterparts, suggesting control by the chemistry of the diagenetic fluid (Fig. 2; Brand and Veizer, 1980). Similarly, the Sr and Mn contents of the Silurian lime mudstone are significantly different from those of the coeval brachiopod bLMC, confirming a diagenetic impact on the former carbonate material (Fig. 2). The carbon and oxygen isotopes of the Eocene and Oligocene provide additional evidence supporting the presumption of preservation for the former and alteration for the latter. The $0^{13} \mathrm{C}$ values of the preserved Eocene bLMC vary from +1.20 to $+1.44 \%$ ( $\mathrm{PDB}$ ), which are similar to values of aragonitic bivalves (e.g., Ivany et al., 2008) and are in stark contrast to the -4.44 to $-4.53 \%$ o for the altered Oligocene bLMC (Appendix 2). This observation is supported by their respective $8^{18} \mathrm{O}$ values that are +0.65 to $0.76 \%$ for the Eocene bLMC and -7.04 to $-6.47 \%$ for the Oligocene counterparts (Appendix 2).

Thus, the geochemical compositions of the Eocene and Silurian bLMC shells (minor elements and carbon and oxygen isotopes) in conjunction with microstructural observations reflect a high degree of preservation (cf. Azmy et al., 1998; Figs. 1 and 2 ) and thus discount any diagenetic reset. This conclusion is further supported by their $(\mathrm{Sm}, ! \mathrm{Yb}) \mathrm{sN}$ ratios $(0.1-0.4)$, which are within the range suggested for modern ocean waters (cf. Grandjean et al., 1987; Zhang and Nozaki, 1996; Lecuyer et al., 2004) and that of the investigated modern brachiopods (0.01-3.4). The investigated suite of samples also included altered carbonates such as recrystallized brachiopods, lime mudstones and burial calcite cements. Specifically, they consist of Oligocene brachiopod shells altered in an open diagenetic (phreaticmeteoric water) system, Silurian lime mudstone and Early Ordovician recrystallized lime mudstone (10-40 f.Ull) altered in partly closed systems in the presence of phreatic-meteoric water (cf. Azmy et al., 2008), and burial calcite cements with entrapmenttemperatures (Th) between 68 and 87 CC (cf. Azmy et al., 2008, 2009) precipitated in an essentially open diagenetic system from burial fluids.

\section{Results}

\section{1. biMC (biogenic low-Mg calcite)}

REE analyses of the investigated carbonate samples (including bLMC) and their statistics are summarized in Appendix 2 and Table 1. Brachiopods from shallow marine settings with annual temperature ranges between 12 and 25 cC represent the warm-water environment, and those with annual temperatures ranging between 0 and 17 CC represent the cold-water environment group. Table 1 summarizes the statistics of the REE concentrations in the modern warmand cold-water brachiopods shells and also those in well-preserved warm-water Silurian counterparts, partially altered lime mudstones (Ordovician and Silurian) and late, deep-burial calcite cements that were included in the study for comparison purposes. The modern warm-water shells have an average IREE concentration of -0.22 ppm, which is comparable to that of their cold-water counterparts of $-0.25 \mathrm{ppm}(\mathrm{p}=0.615$, Table 2). The same holds true for their REEsN trend values $(p=0.218$, Table 2$)$, but they are significantly different for those brachiopods from 'special' environmental settings (i.e., siliciclastic and cool environment; $p=0.007$, Table 2 ). This group of 'mainstream' warm- and cold-water brachiopods (Appendix 2) represents 14 species of the Order Terebratulida, whereas an additional9 species representing the Orders Terebratulida, Thecideida and Rynchonellida make up the group from 'special' environmental settings such as areas of upwelling, riverine flux, and aerosol dust deposition. An additional 8 specimens, representing one species, are from a siliclastic environment of deposition, with IREE and REEsN trend significantly different from those of the warm- and cold-water regime brachiopods (Table 2). The major difference in the modern brachiopods from the siliciclastic environment is their slight enrichment in the MREE and HREE with the exception of Ho, relative to the other modern 'mainstream' brachiopods (Fig. 3). The CesN anomaly values of the warm- and cold-water modern brachiopods are negative but show a considerable range, whereas their LasN anomaly values range from slightly negative to mostly positive (Fig. 4), these features and their REEsN trends reflect open ocean water conditions (cf. Elderfield, 1988; Lee and Byrne, 1993; Webb and Kamber, 2000).

In contrast, modern brachiopods from environments of elevated nutrient levels (upwelling, riverine flux, and aerosol dust deposition) of both warm- and cold-water regimes exhibit elevated REEsN trends relative to that of the "mainstream' brachiopods with the highest 

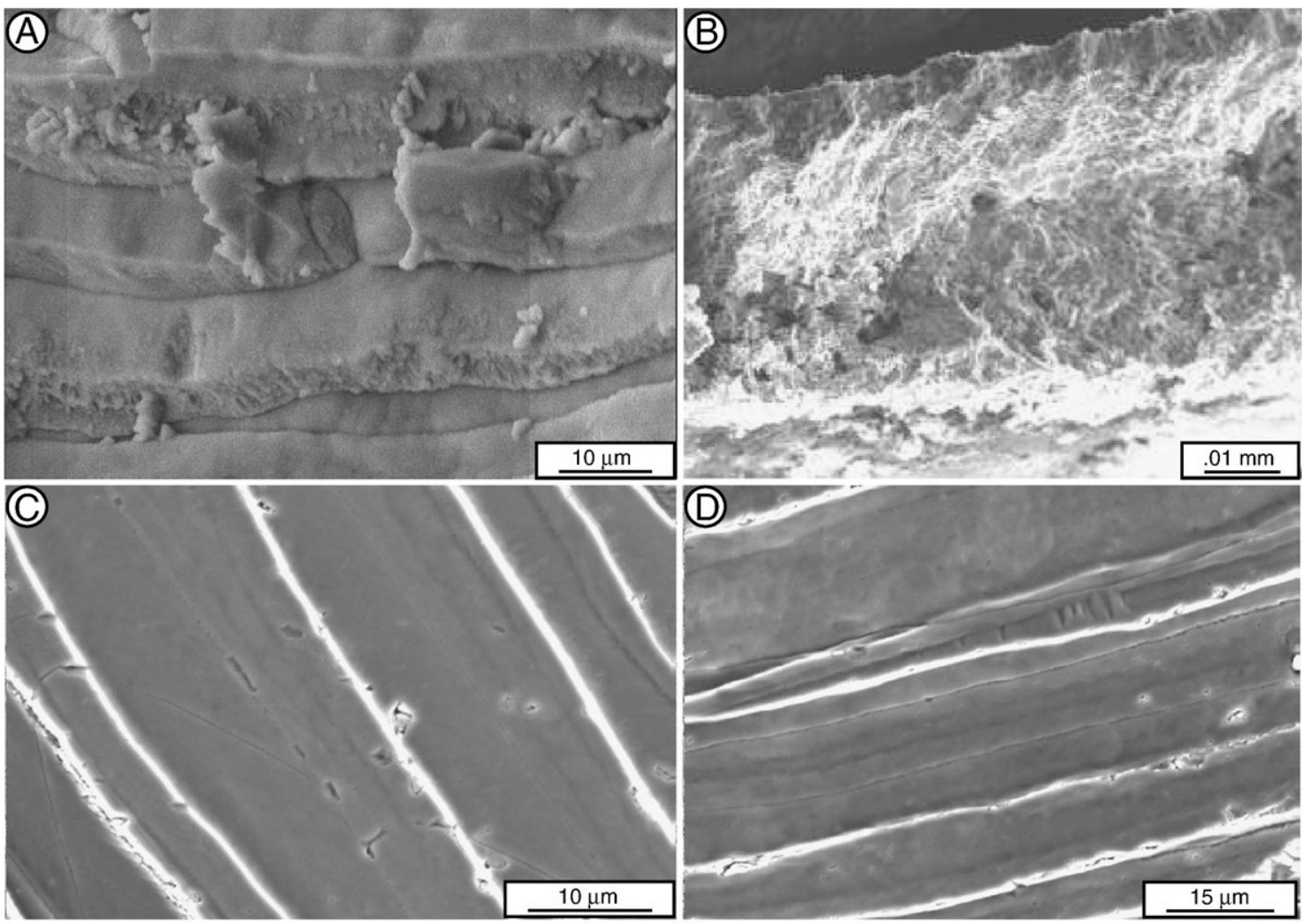

Fig.1. Microstructures in brachiopod shells from the Eocene of Seymour Island (A, well-preserved fibers.\#SIT-93) and from King George Island (B, disrupted structure and filling by coarse calcite, \#SIT-97). Well-preserved fibers in brachiopods from the Silurian of Anticosti Isalnd (C, \#A800 and D, \#A922).

levels documented by those from extrinsic warm-water regimes (Fig. 5). From the paucity of results, it is obvious more material is required to fully characterize the impact of changing seawater nutrient levels and other extrinsic environmental parameters on the REE contents of bLMC.

Brachiopods from different water depths should follow REE trends observed in modern seawater REE, however, no clear REE trend with water depth was observed in the modern brachiopod bLMC database, this maybe an artifact of simply insufficient material from a single geographic location. Perhaps, future studies on brachiopods from a single location and spanning great water depths may resolve this open issue.

A set of preserved brachiopods (cf. Ivany et al., 2008) was analyzed from the Eocene of Seymour Island, and from the Silurian of Anticosti Island (Figs. 1 and 2; Appendix 2). The overall REEsN trend of the Eocene brachiopods is similar to that of the modern open-ocean ones, but shows a slight enrichment of REEsN contents by about a factor of five (Fig. 6). The REEsN trend for the Silurian brachiopods is also similar to that of its modern open-ocean counterparts, but their overall REEsN trends falls within the upper part of the modern

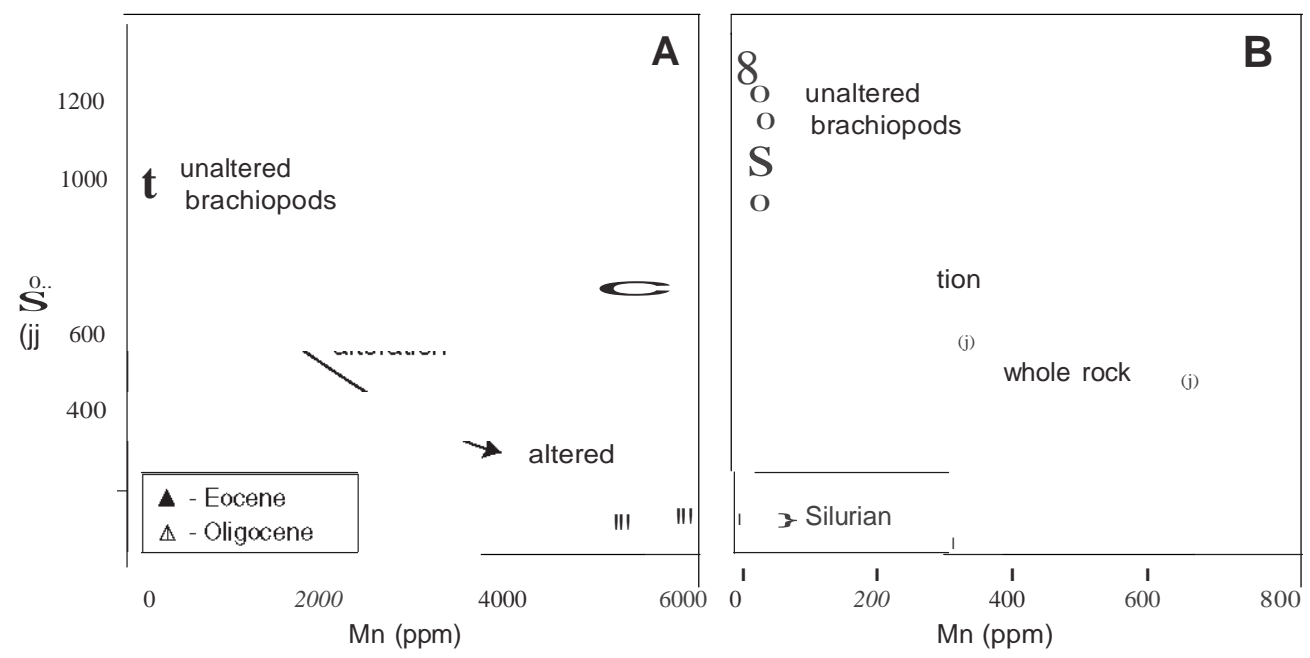

Fig. 2. Distribution of Sr and Mn contents in well-preserved Eocene (A) and Silurian (B) brachiopods and in alt ered counterparts Oligocene and Silurian lime mudstone. Wellpreserved Eocene and Silurian brachiopods have Sr and Mn contents similar to those observed in their modern counterparts (cf. Brand et al., 2003). In contrast, coeval alt ered brachiopods and lime mudstone are depleted in Sr and enriched in Mn with progressive diagenetic alteration (cf. Brand and Veizer, 1980; Veizer, 1983). 
Table 1

Summary statistics of modern brachiopods, Silurian brachiopods and coeval lime mudstone, and of several Ordovician lime mustones and corresponding burial cements.

\begin{tabular}{|c|c|c|c|c|c|c|c|c|c|c|c|c|c|c|c|}
\hline & $\begin{array}{l}\text { La } \\
\text { (ppb) }\end{array}$ & $\begin{array}{l}\mathrm{Ce} \\
(\mathrm{ppb})\end{array}$ & $\begin{array}{l}\mathrm{Pr} \\
\text { (ppb) }\end{array}$ & $\begin{array}{l}\mathrm{Nd} \\
(\mathrm{ppb})\end{array}$ & $\begin{array}{l}\mathrm{Sm} \\
(\mathrm{ppb})\end{array}$ & $\begin{array}{l}\mathrm{Eu} \\
(\mathrm{ppb})\end{array}$ & $\begin{array}{l}\mathrm{Gd} \\
(\mathrm{p} \mathrm{pb})\end{array}$ & $\begin{array}{l}\mathrm{Tb} \\
(\mathrm{ppb})\end{array}$ & $\begin{array}{l}\text { Dy } \\
\text { (ppb) }\end{array}$ & $\begin{array}{l}\text { Ho } \\
\text { (ppb) }\end{array}$ & $\begin{array}{l}\mathrm{Er} \\
(\mathrm{ppb})\end{array}$ & $\begin{array}{l}\mathrm{Tm} \\
(\mathrm{ppb})\end{array}$ & $\begin{array}{l}\mathrm{Yb} \\
(\mathrm{ppb})\end{array}$ & $\begin{array}{l}\text { Lu } \\
\text { (ppb) }\end{array}$ & $\begin{array}{l}\begin{array}{l}\text { 2..: REE } \\
(\mathrm{ppm})\end{array}\end{array}$ \\
\hline \multicolumn{16}{|c|}{ Modern warm-water brachiopods } \\
\hline$n$ & 13 & 13 & 13 & 13 & 13 & 5 & 13 & 12 & 13 & 6 & 8 & 6 & 8 & 4 & 13 \\
\hline Average & 115.71 & 66.95 & 7.43 & 31.13 & 5.92 & 1.15 & 8.52 & 1.05 & 6.17 & 1.68 & 4.82 & 0.76 & 3.35 & 0.71 & 0.25 \\
\hline Stdev & 175.16 & 35.37 & 5.15 & 20.91 & 4.05 & 0.56 & 6.99 & 1.12 & 6.84 & 1.33 & 5.05 & 0.62 & 3.46 & 0.46 & 0.19 \\
\hline Max & 529.96 & 130.D7 & 16.90 & 64.46 & 13.86 & 1.95 & 19.08 & 3.33 & 17.38 & 3.42 & 12.22 & 1.77 & 9.81 & 0.98 & 0.73 \\
\hline Min & 16.58 & 18.68 & 0.36 & 4.28 & 1.67 & 0.49 & 1.95 & 0.03 & 0.26 & 0.22 & 0.15 & 0.03 & 0.59 & 0.02 & 0.05 \\
\hline \multicolumn{16}{|c|}{ Modern cold-water brachiopods } \\
\hline$n$ & 25 & 25 & 24 & 25 & 21 & 12 & 25 & 17 & 19 & 21 & 21 & 13 & 20 & 11 & 25 \\
\hline Average & 57.65 & 60.89 & 10.09 & 44.57 & 10.14 & 2.00 & 16.79 & 1.65 & 7.25 & 2.02 & 6.12 & 0.80 & 8.42 & 0.78 & 0.22 \\
\hline Stdev & 41.52 & 44.56 & 7.24 & 34.93 & 10.46 & 2.54 & 23.02 & 1.87 & 6.09 & 2.83 & 6.02 & 0.82 & 12.66 & 0.96 & 0.15 \\
\hline $\operatorname{Max}$ & 192.24 & 163.80 & 35.57 & 138.52 & 49.16 & 9.27 & 75.79 & 7.10 & 23.71 & 12.51 & 23.04 & 2.78 & 44.07 & 3.17 & 0.66 \\
\hline Min & 12.17 & 1.69 & 1.25 & 1.57 & 0.82 & 0.37 & 0.17 & 0.22 & 0.00 & 0.02 & 1.30 & 0.10 & 0.22 & 0.01 & O.D3 \\
\hline \multicolumn{16}{|c|}{ Silurian brachiopods } \\
\hline$n$ & 10 & 10 & 10 & 10 & 10 & 10 & 10 & 10 & 10 & 10 & 10 & 10 & 10 & 10 & 10 \\
\hline Average & 500.49 & 820.17 & 106.04 & 433.45 & 77.06 & 16.58 & 86.82 & 12.01 & 67.83 & 13.33 & 36.98 & 3.26 & 29.61 & 2.76 & 2.21 \\
\hline Stdev & 206.99 & 521.31 & 45.73 & 184.39 & 31.23 & 8.23 & 37.57 & 5.76 & 32.56 & 6.09 & 19.49 & 2.33 & 14.14 & 1.60 & 1.01 \\
\hline $\operatorname{Max}$ & 798.55 & 2038.23 & 169.38 & 677.95 & 141.09 & 28.58 & 157.49 & 22.95 & 135.05 & 24.90 & 71.46 & 8.30 & 60.79 & 5.16 & 3.82 \\
\hline Min & 180.08 & 263.77 & 43.36 & 161.89 & 30.13 & 2.98 & 31.84 & 4.87 & 25.30 & 6.88 & 13.44 & 0.92 & 14.77 & 0.09 & 0.79 \\
\hline \multicolumn{16}{|c|}{ Silurian lime mudstone (altered) } \\
\hline$n$ & 2 & 2 & 2 & 2 & 2 & 2 & 2 & 2 & 2 & 2 & 2 & 2 & 2 & 2 & 2 \\
\hline Average & 4768.00 & 8479.50 & 1127.50 & 4565.50 & 863.50 & 199.50 & 950.00 & 139.00 & 785.00 & 164.50 & 417.00 & 47.50 & 318.50 & 47.00 & 22.88 \\
\hline Stdev & 1651.80 & 3690.39 & 514.07 & 1897.17 & 474.47 & 99.70 & 386.08 & 62.23 & 282.84 & 34.65 & 96.17 & 24.75 & 108.19 & 16.97 & 9.34 \\
\hline Max & 5936.00 & 11089.00 & 1491.00 & 5907.00 & 1199.00 & 270.00 & 1223.00 & 183.00 & 985.00 & 189.00 & 485.00 & 65.00 & 395.00 & 59.00 & 29.48 \\
\hline Min & 3600.00 & 5870.00 & 764.00 & 3224.00 & 528.00 & 129.00 & 677.00 & 95.00 & 585.00 & 140.00 & 349.00 & 30.00 & 242.00 & 35.00 & 16.27 \\
\hline \multicolumn{16}{|c|}{ rraovician Aguatnuna $\mathrm{rm}$. ılme muastone (atterea) } \\
\hline$n$ & 5 & 5 & 5 & 5 & 5 & 5 & 5 & 5 & 5 & 5 & 5 & 5 & 5 & 5 & 5 \\
\hline Average & 2032.85 & 3748.62 & 475.60 & 1507.02 & 246.28 & 51.83 & 266.96 & 29.44 & 148.27 & 25.63 & 81.14 & 9.29 & 66.05 & 8.33 & 8.70 \\
\hline Stdev & 1355.80 & 2733.22 & 387.10 & 1126.78 & 179.85 & 38.23 & 190.08 & 20.67 & 102.67 & 18.44 & 58.00 & 7.04 & 48.28 & 6.27 & 6.25 \\
\hline Max & 3911.99 & 7485.90 & 935.53 & 3008.85 & 481.20 & 95.39 & 520.34 & 56.49 & 271.56 & 47.93 & 144.26 & 17.82 & 122.93 & 16.30 & 17.04 \\
\hline Min & 81628 & 120470 & $148 \Lambda 1$ & 51272 & 8425 & 1876 & 1 10 50 & о १о & 1417 & 867 & ว8 व० & 224 & 3418 & 010 & 374 \\
\hline \multicolumn{16}{|c|}{ Ordovician Aguathuna Fm. burial cement } \\
\hline$n$ & 5 & 5 & 5 & 5 & 5 & 5 & 5 & 5 & 5 & 5 & 5 & 5 & 5 & 5 & 5 \\
\hline Average & 11067.08 & 18848.69 & 1963.41 & 6798.70 & 950.82 & 193.42 & 1122.29 & 113.10 & 460.73 & 81.58 & 226.74 & 25.44 & 153.82 & 22.72 & 42.03 \\
\hline Stdev & 6572.57 & 7554.34 & 622.23 & 1905.62 & 329.37 & 76.47 & 314.05 & 45.26 & 217.82 & 37.55 & 91.46 & 10.78 & 64.11 & 10.19 & 16.30 \\
\hline $\operatorname{Max}$ & 20436.30 & 28011.02 & 2657.64 & 9135.40 & 1240.04 & 275.36 & 1427.32 & 173.63 & 774.24 & 139.82 & 360.50 & 40.74 & 236.11 & 34.25 & 60.96 \\
\hline Min & 4056.81 & 10683.94 & 1118.35 & 3965.21 & 536.04 & 107.43 & 659.85 & 64.16 & 235.83 & 48.72 & 135.92 & 15.76 & 80.89 & 10.84 & 23.84 \\
\hline \multicolumn{16}{|c|}{ Ordovician 8oat Harbour Fm. lime mudstone (altered) } \\
\hline$n$ & 5 & 5 & 5 & 5 & 5 & 5 & 5 & 5 & 5 & 5 & 5 & 5 & 5 & 5 & 5 \\
\hline Average & 3509.04 & 6966.43 & 751.82 & 2735.90 & 460.41 & 99.86 & 505.13 & 62.03 & 303.12 & 56.82 & 175.D7 & 21.18 & 146.77 & 19.02 & 15.81 \\
\hline Stdev & 1857.17 & 3677.20 & 381.62 & 1371.52 & 215.52 & 51.14 & 283.44 & 32.71 & 168.79 & 32.83 & 103.17 & 14.22 & 81.47 & 12.88 & 8.26 \\
\hline Max & 5747.01 & 11773.26 & 1235.55 & 4456.65 & 724.54 & 167.88 & 913.14 & 106.80 & 535.99 & 102.66 & 323.23 & 42.18 & 254.15 & 38.13 & 26.42 \\
\hline Min & 1327.25 & 2325.38 & 269.66 & 960.30 & 178.91 & 32.44 & 159.79 & 21.07 & 96.57 & 18.36 & 57.16 & 5.34 & 52.69 & 3.92 & 5.51 \\
\hline \multicolumn{16}{|c|}{ Ordovician 8oat Harbour Fm. burial cement } \\
\hline$n$ & 3 & 3 & 3 & 3 & 3 & 3 & 3 & 3 & 3 & 3 & 3 & 3 & 3 & 2 & 3.00 \\
\hline Average & 2235.15 & 3982.84 & 485.67 & 1788.98 & 294.70 & 60.45 & 297.63 & 31.22 & 115.69 & 21.20 & 62.83 & 8.66 & 59.32 & 8.36 & 9.45 \\
\hline Stdev & 1004.37 & 1090.71 & 123.43 & 446.91 & 140.22 & 15.49 & 96.15 & 12.58 & 96.56 & 11.25 & 26.65 & 1.09 & 12.06 & 1.23 & 2.37 \\
\hline Max & 3222.12 & 5158.18 & 620.80 & 2290.05 & 444.50 & 78.24 & 407.31 & 44.61 & 189.15 & 29.65 & 84.95 & 9.68 & 70.67 & 9.23 & 11.69 \\
\hline Min & 1214.24 & 3003.28 & 378.86 & 1431.56 & 166.59 & 49.92 & 227.84 & 19.64 & 6.33 & 8.43 & 33.24 & 7.52 & 46.66 & 7.49 & 6.98 \\
\hline
\end{tabular}


Table 2

Statistical ANOVA analysis of:i.REE (ppm) and REE series (La-Lu; PAAS normalized) for modern brachiopods from cold (c), warm (w), and intermediate (in) watertemperature environments (Appendix). Population means are evaluated at the 95\% confidence level (with a $p$ of 0.050 ).

\begin{tabular}{|c|c|c|c|c|}
\hline \multicolumn{5}{|l|}{$\mathrm{J} ; R E E$} \\
\hline (c) brachiopods & $\mathrm{N}$ & (w) brachiopods & $\mathrm{N}$ & $p$ \\
\hline 0.2208 & 25 & 0.2492 & 13 & 0.615 \\
\hline \multicolumn{5}{|l|}{ REE series } \\
\hline (c) brachiopods & $\mathrm{N}$ & (w) brachiopods & $\mathrm{N}$ & $p$ \\
\hline $\begin{array}{l}0.001948 \\
\text { (c and w) brachiopods }\end{array}$ & 14 (25) & $\begin{array}{l}0.001571 \\
\text { (in) brachiopods }\end{array}$ & $14(13)$ & 0.218 \\
\hline 0.001760 & 14 (38) & 0.007553 & 13(8) & 0.007 \\
\hline
\end{tabular}

brachiopod REE field (Fig. 6). This apparent REEsN enrichment may be a reflection of secular seawater change, and/or differences in intrinsic or extrinsic environmental conditions. An evaluation of the Eocene and Silurian CesN and LasN anomalies shows that their ratios are similar to those of the modern brachiopods, and analogous to them also reflect open surface-seawater conditions (Fig. 7). Based on this small fossil database, brachiopod bLMC may hold promise as a seawater-REE proxy, but more studies of well-preserved brachiopods from other geologic time periods are needed to clarity this issue.

\subsection{Diagenetic carbonates}

To test the resistance of REE contents to diagenesis (cf. Banner et al., 1988; Webb et al., 2009), brachiopods and whole rock (lime mudstones) were chosen that were affected by two distinctly different diagenetic processes. The brachiopods from the Oligocene of Seymour Island show the total disruption of microstructures and concurrent changes in trace chemistry (Figs. 1 and 2) and stable isotopes consistent with phreatic meteoric-water alteration in an open diagenetic system (cf. Brand and Veizer, 1980, 1981).The altered Oligocene brachiopods are enriched by about one order of magnitude in REEsN relative to those of their well-preserved Eocene cousins (Fig. 8). Furthermore, the enclosing and thus coeval whole rock (lime mudstone) of the well-preserved Silurian brachiopods was interpreted to have undergone phreatic meteoric-water diagenesis in a partly closed system, documented by the shifts in trace element concentrations (Fig. 2) and insignificant ones for the stable isotopes (Azmy et al., 1998); these were deemed to be good materials for the examination of its REE chemistry. Despite its partly closed system

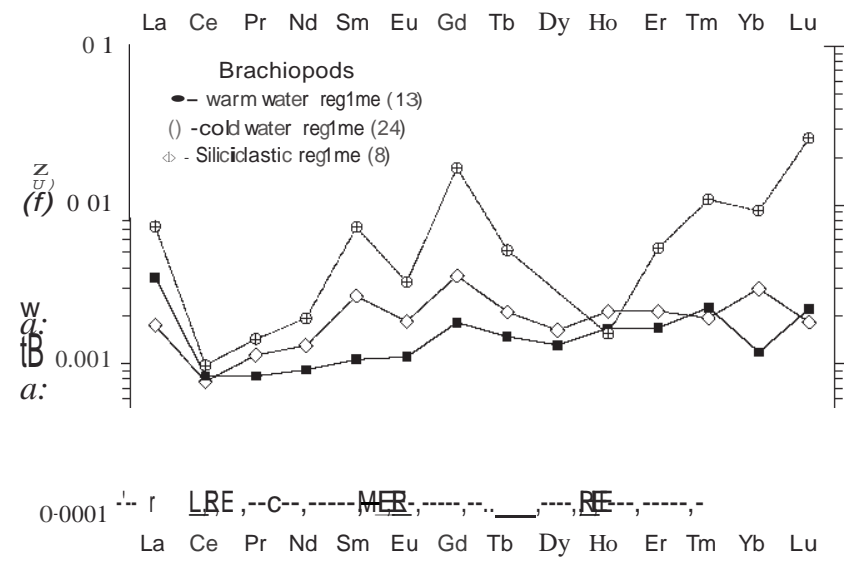

Fig.3. Mean shale-normalized (PAAS) values ofREE concentrations in modern brachiopod shells. Three groups: warm-, cold-water and siliciclastic regimes are recognized in the modern brachiopod REE population. REEs N trends of the three groups show the distinct Ce depletion. The 'anomalous' MREE and HREE contents of the third group are indicative of their siliciclastic seafloor environment of deposition (Tables land 2).

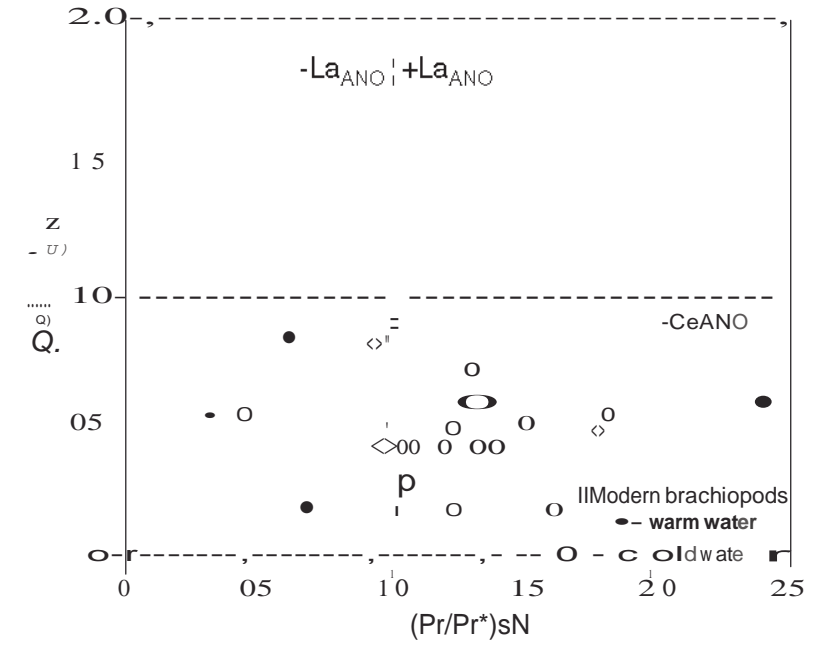

Fig. 4. Ce (Ce/CesN)-La (Pr/PrsN) anomaly evaluation of the modern warm- and coldwater open ocean brachiopods. The equations of Bau and Dulski (1996) were used to calculate the values, and to define the positive and negative Ce and La anomaly fields. Modern brachiopods exhibit mostly negative Ce anomalies with predominantly positive La anomalies.

diagenetic alteration, the REEsN contents of the Silurian lime mudstones are significantly different (higher), by about one order of magnitude, than those of their coeval and well-preserved brachiopods (Fig. 8). Examination of the Ce anomaly and Mn contents of the Eocene/Oligocene and Silurian brachiopod/lime mudstone pairs shows a clear increase in the Mn concentrations with alteration and some slight shifts in Ce anomaly with diagenesis (Fig. 9). These observations suggest that both REEs and REEsN trends and associated shifts in the altered carbonates are sensitive indicators of phreatic meteoric-water diagenesis of partly closed to open system microenvironments, while potentially preserving their REEsN seawater pattern (Fig. 8).

On the other hand, host carbonates (lime mudstones) and their burial calcite cements of two Ordovician formations depict a more complex scenario of REEsN distribution with burial diagenesis. In the instance of the material from the Boat Harbour Formation, the burial calcite cement REEsN trend is parallel and slightly depleted (by a factor of about 3) relative to that of their coeval host carbonate (lime mudstone; Fig. 10). This similarity in REEsN trends suggests some burial fluid interaction with the host lime mudstone during emplacement of the burial calcite cement in a diagenetically open system and sourced by burial fluids. Furthermore, both REEsN trends do not exhibit the typical seawater pattern, but a general enrichment of the LREEs and some MREEs and an overall 'smoothing' of the trend resembling a 'chevron' (Fig. 10). This variance in REEsN contents and trends of the host lime mudstone and its burial calcite cement is also mirrored by subtle differences in their respective Ce anomalies and Mn contents (Fig. 11).

In contrast, the burial calcite cement from the Aguathuana Formation exhibit REEsN contents enriched (by a factor of about 4) relative to that of the host lime mudstone (Fig. 10). Besides this slight enrichment in $\mathrm{REE}_{5} \mathrm{~N}$, their trends are subparallel to each other and exhibit the 'chevron' pattern also noted for the host rock and burial calcite cement of the Boat Harbour Formation (Fig. 10). Besides the REEsN enrichment of the burial calcite cement relative to the host lime mudstone, the former exhibit a significantly higher Mn content and a slightly less negative Ce anomaly than of the enclosing or host rock material (Fig. 11). Finally, the evaluation of the Ce and La anomalies suggest that the burial calcite cements from the Boat Harbour and Aguathuana Formations precipitated in equilibrium from burial fluids (Fig. 12), and that the chemical differences in calcite cements reflect differences in burial fluid composition (Figs. 10 and 12). These 


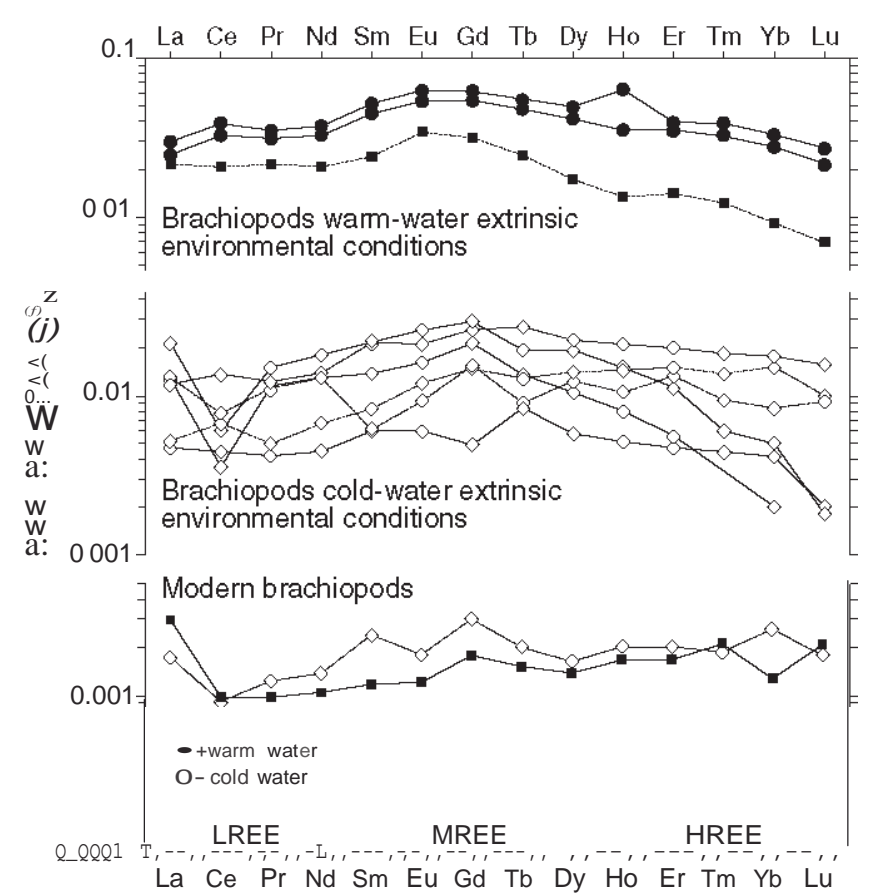

Fig. 5. Mean REEsN contents of the baseline modern group of warm- and cold-water regime brachiopods and the REEsN trends of modern brachiopods from areas of warmwater and cold-water extrinsic environmental conditions such as upwelling, riverine flux and aerosol dust deposition.

observations suggest that REEsN distribution during burial diagenesis and in the presence of burial fluids may be quite complicated in contrast to carbonate diagenesis in the presence of meteoric water within the vadose or phreatic zones or dolomitization by microbially mediated mixed water. Evidently, more work is needed to resolve the divergent REESN trends and compositions for all types of diagenetic processes (i.e., vadose, phreatic, mixed, burial diagenesis).

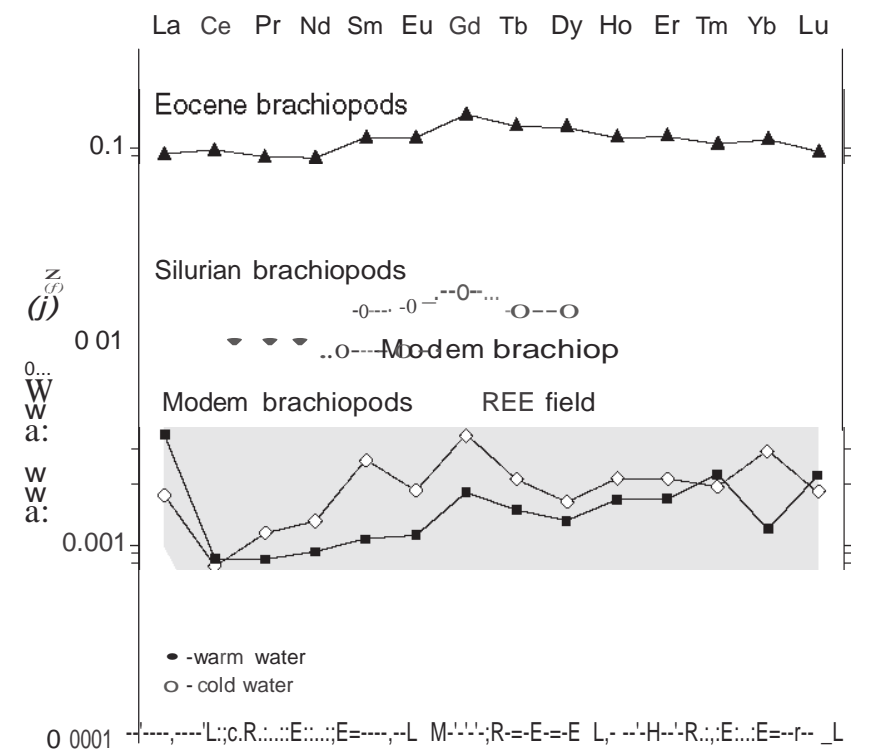

La Ce Pr Nd Sm Eu Gd Tb Dy Ho Er Tm Yb Lu

Fig. 6. Mean REEsN contents of modern warm- and cold water brachiopods and REE field encompassing all modern brachiopod results, and their well-preserved Eocene and Silurian counterparts (Table 1, Appendix 2). The mean REEs N trends of the Eocene and Silurian brachiopods preserved the charact eristic seawat er patter, albeit with slig htly enriched REE contents, which may reflect extrinsic environmental conditions and/or epeiric seawater influences.

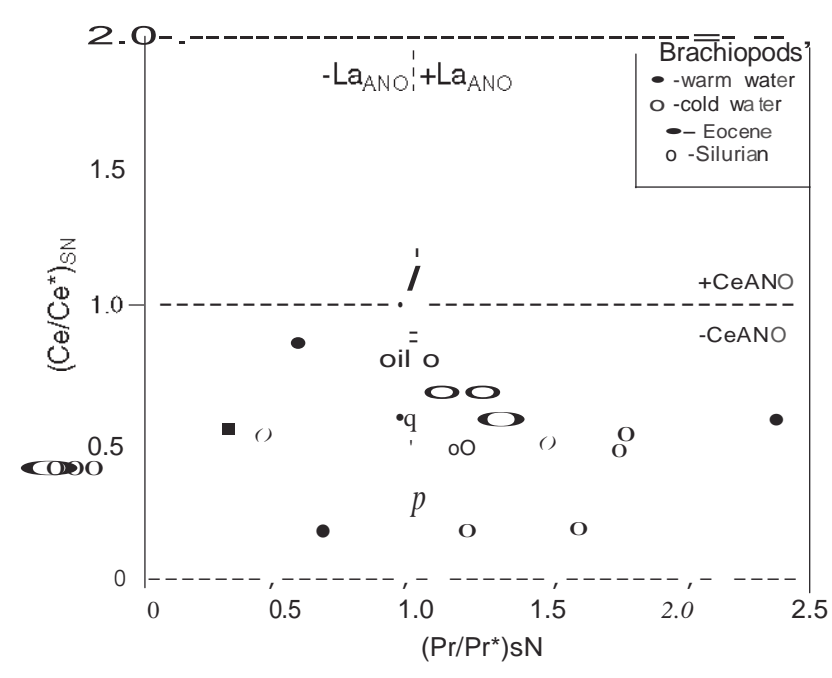

Fig. 7. Eocene and Silurian brachiopod $\mathrm{Ce}$ and La anomaly values overlap with those of their modern counterparts, with the Eocene ones exhibiting minor positive Ce anomalies coupled with a slight negative La anomaly. Extrinsic environmental conditions may play a major factor in these REE and Ce anomaly results. Anomaly equations used are from Bau and Dulski(1996).

\section{Discussion}

\subsection{Vital effect}

The similar mean values of the 2.REE of both warm- and cold-water brachiopod populations $(0.25 \pm 0.19 \mathrm{ppm}$ and $0.22 \pm 0.15 \mathrm{ppm}$, respectively) are associated with considerable standard deviations (Table 1). This is attributed, in part, to wide interspecies variations of 2.REE among each population such as the variations between the values from Gryphus vitreus and Megerlia truncata (both from Marseille, France) and intraspecies variations observed in Magel/ania Jlavescens shells (Appendix 2). However, the intraspecies variations in 2.REE concentrations are at times as high as their interspecies counterparts (Appendix 2) such as the cases of the Terebratulina septentrionalis $(0.3 \pm 0.2, n=7)$ and Magel/ania flavescens $(0.6 \pm 0.2$, $\mathrm{n}=7$ ) shells, which may suggest that the vital effect (intrinsic) is likely insignificant but other local environmental factors (extrinsic conditions such as upwelling, riverine flux, aerosol dust deposition) may be quite influential on brachiopod bLMC REE composition.

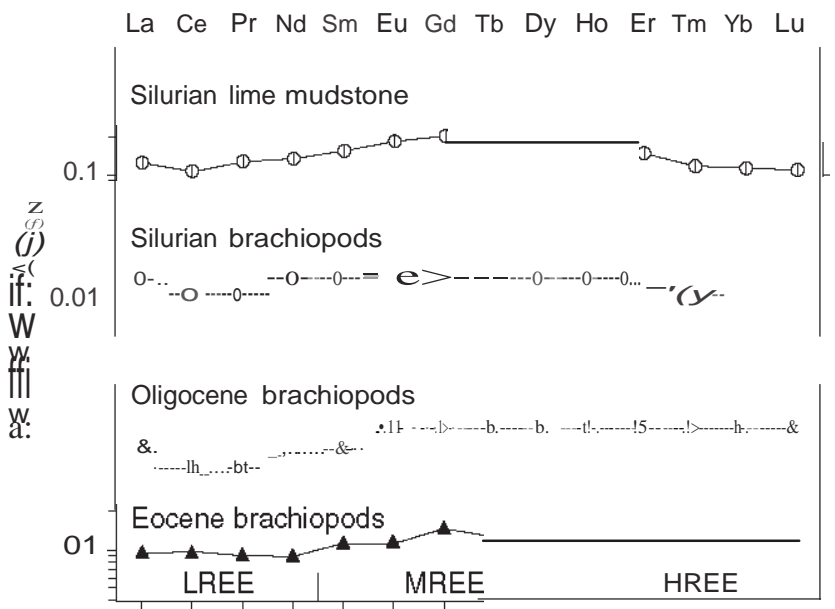

La Ce Pr Nd Sm Eu Gd Tb Dy Ho Er Tm Yb Lu

Fig. 8. Mean REEs N trends of well-preserved Eocene and Silurian, and corresponding diagenetic material of Oligocene brachiopods and Silurian lime mudstone, respectively. The diagenetic carbonat es are enriched in REESN contents by about an order of magnitud e relative to those of their corresponding well-preserved carbonates. 


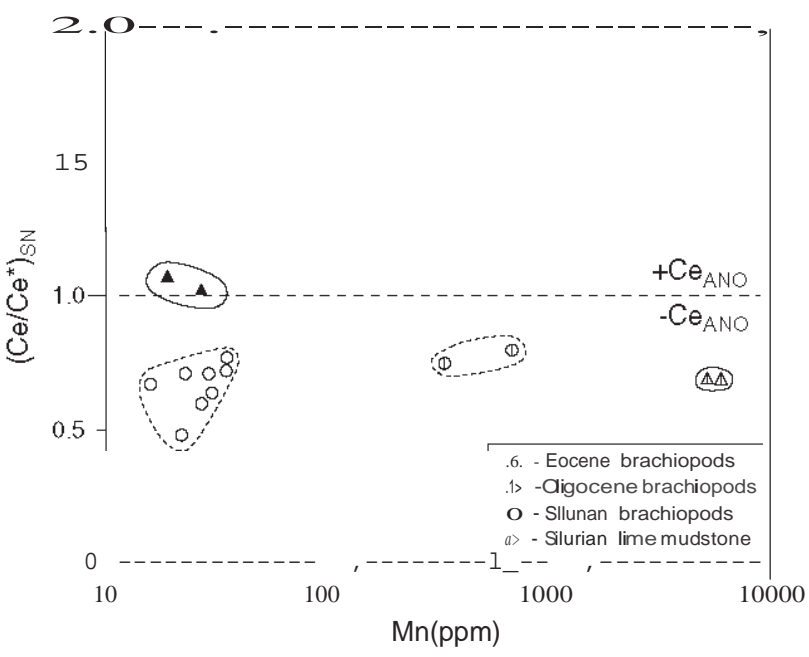

Fig. 9. Ce anomaly and Mn distribution in the well-preserved Eocene and Silurian brachiopods and their corresponding diagenetic counterparts of Oligocene brachiopods and Silurian lime mudstone. Mn content increases with diagenesis in phreatic meteoric water (Brand and Veizer, 1980) and is coupled by either a depletion (Oligocene b!MC) or slight enrichment (Silurian mudstone) in Ce anomaly values.

\subsection{Temperature effect}

Some of the modern shells have outliers with high 2.REE contents (Appendix 2), compared with the rest of the studied population, such as the Bouchardia rosea from warm shallow water setting (Sao Paulo, Brazil) and the Hispanirhynchia cornea from cold, deep water settings (Canary Islands). Although these two came from different temperature regimes, both were collected from oceanic zones influenced by upwelling currents (cf. Barton et al., 1998; Ferreira et al., 1999). On the other hand, brachiopods from very cold waters (0-6 DC) of high latitudes such as the Liothyrel/a notorcadensis from Arthur Harbour (Antarctica) and Terebratella sanguinea from Steward Island (New Zealand) and from deep settings at low latitudes (e.g., Chlidonophora incerta, Puerto Rico and Hispanirhynchia cornea, Canary Islands) have also high 2.REE contents (Appendix 2), which are consistent with the generally high REE concentrations documented for deep and cold ocean waters (e.g., Zhang and Nozaki, 1996) that are usually rich in

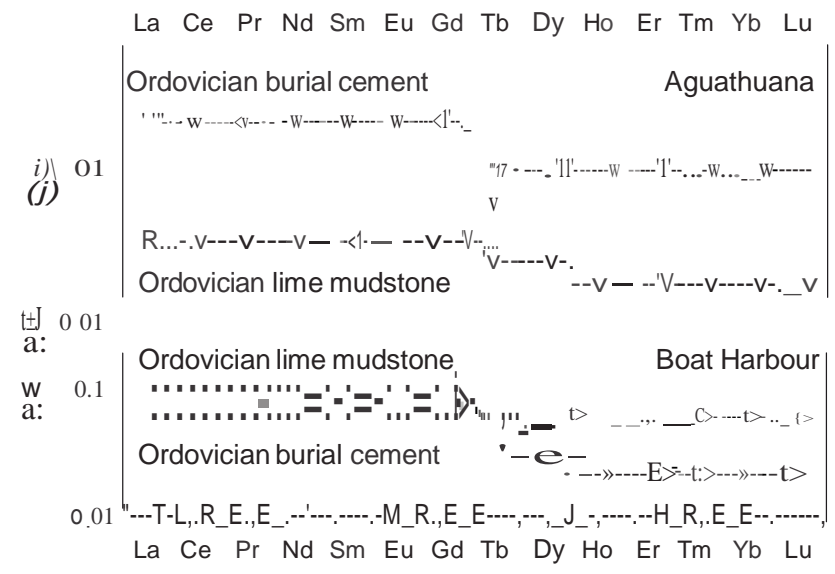

Fig.10. Mean REEsN contents of Ordovician diagenetic lime mudstone and associated burial calcite cement from the Boat Harbour and Ag uathuana Formations, respectively. The burial cement from the Ordovician Aguathuana Formation shows the greatest REEs N enrichment. The diagenetic carbonates have REEs N trends with slightly enriched LREE and depleted HREE relative to that of modern seawater. This 'chevron' pattern of both the burial calcite cements and host lime mudstones suggest precipitation in a diagenetic open system with the chemistry of the fluid controlling the solid phase chemistry.

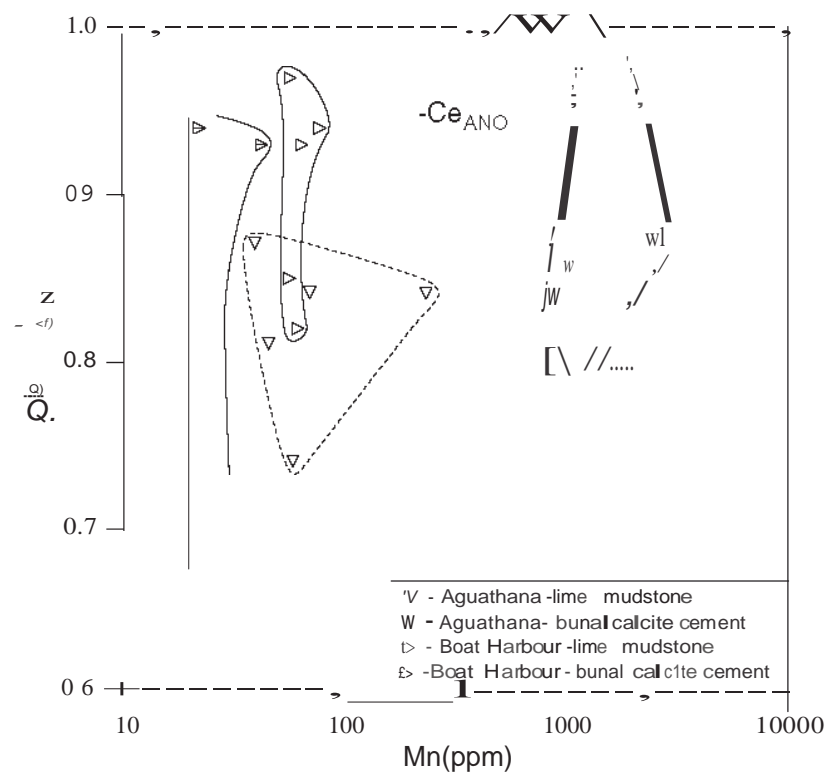

Fig. 11. Ce anomaly and Mn plot of Ordovician lime mudstones and burial calcite cements. The burial fluids maintained the negative $\mathrm{Ce}$ anomaly indicative of oxic conditions, whereas the Mn chemistry suggests a strong fluid chemistry control that of the calcite cements.

nutrients. Similarly, Megerlia truncate from Marseille, France was collected near the discharge area of the Rhone River and it therefore has higher 2.REE (2.7 ppm) than that of a Gryphus vitreus shell $(0.2 \mathrm{ppm})$ collected from the same general locality, comparable in depth but slightly removed from the riverine input (Appendix 1; Brand et al., 2003). The high 2.REE in the riverine detrital input possibly influenced the ultimate REE composition of the Megerlia truncate blMC.

When the distinctly high 2.REE values of samples influenced by upwelling and riverine input are excluded from statistical calculations (Table 2), the difference between the mean 2.REE of cold-water population $(0.22 \pm 0.2 \mathrm{ppm})$ and that of warm-water population $(0.25 \pm 0.2 \mathrm{ppm})$ is within the range of standard deviations (Table 1$)$ and therefore insignificant (Table 2). Also, the individual REEs and

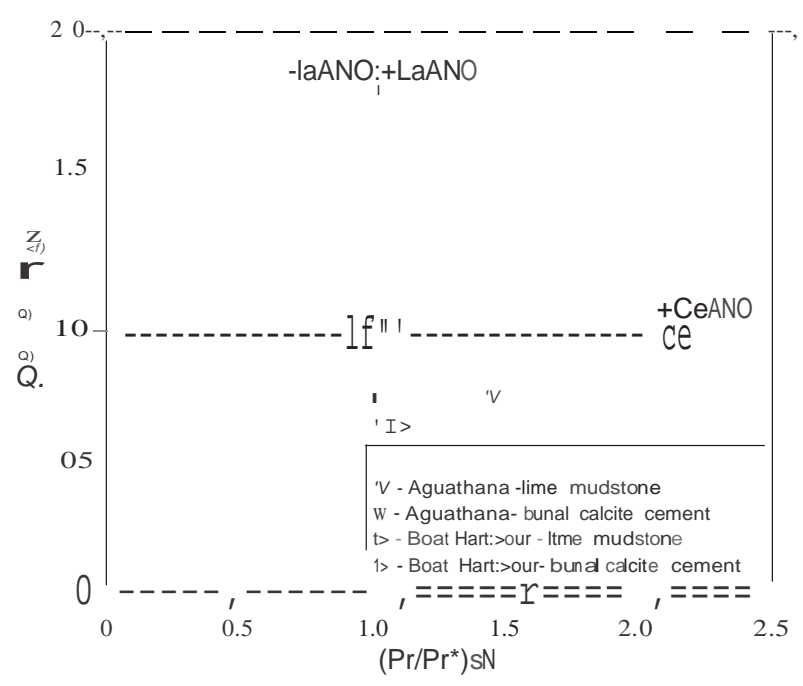

Fig.12. Ce and $\mathrm{Ll}$ anomaly plot of the Ordovician lime mudstones and corresponding burial cements. The values, with few exceptions, cluster close to the unity lines suggesting precipitation and/or diagenetic alt eration in REE equilibrium with their respective diagenetic fluids/water. 
mean tREE contents of the investigated modern brachiopod shells, which mainly cover the upper $1300 \mathrm{~m}$ of ocean water, do not exhibit a strong systematic correlation with depth or temperature like the trend of REEs in ocean waters as was suggested by earlier studies (e.g., Zhang and Nozaki, 1996).

REEs have been widely utilized as redox indicators in marine carbonates (e.g., Sholkovitz and Shen, 1995; Feng et al., 2008; Azmy et al., 2009) phosphate deposits (e.g., McArthur and Walsh, 1984; Wright et al., 1987; Chen et al., 2003) and hydrothermal carbonate deposits (e.g., Barrat et al., 2000). ceH is oxidized to Ce4+ under oxidizing conditions, resulting in a negative Ce anomaly. Therefore, negative Ce anomalies in marine carbonates have been shown to reflect seawater oxygenation (e.g., McArthur and Walsh, 1984; Sholkovitz and Shen, 1995; Shields and Webb, 2004). Except for some modern shells collected from deep cold water and restricted settings (e.g., some of the Magellania Jlavescens shells from the Western Port Bay, Australia), the majority of the studied brachiopod shells exhibit a negative Ce anomaly (Fig. 3), thus suggesting bLMC precipitation under oxic surface seawater conditions (cf. Barton et al., 2006).

Earlier geochemical studies on the Silurian preserved fossil shells of the current studies suggested that they lived in warm-water of about 20-35 ·c (Azmy et al., 1998; Came et al., 2007). These shells have tREE contents $(2.21 \pm 1.0 \mathrm{ppm})$, which are almost comparable to those of their modern counterparts (Fig. 6; Table 1). The occurrence of the fossil shells in limestone beds and their association with corals (cf. Azmy et al., 1998 ) imply that their REE composition most likely reflects that of the ambient seawater in which they lived (e.g., Elderfield et al., 1981) with no significant influence of detrital input. The position of the REEsN trend within the upper part of the modern brachiopod REE field (Fig. 6) might be attributed to minor contributions from upwelling currents, insignificant but small terrestrial input of nutrients, and/or small variations in the REE composition of seawater during the Paleozoic (cf. Picard et al., 2002; Lecuyer et al., 2004; Shields and Webb, 2004). This may suggest, at this stage, that low temperature $(0-30 \cdot \mathrm{q}$ does not seem to significantly influence fractionation of REEs in primary carbonates during bLMC precipitation.

\subsection{Diagenetic effect}

Initially, limestones were considered poor choices of seawater REE proxies, because diagenesis was deemed pervasive and caused increases in REEs in ancient carbonates (e.g., Scherer and Seitz, 1980; Shaw and Wasserburg, 1985). This early concept was replaced by the current paradigm, which suggests that diagenesis, specifically meteoric and mixed water, has no effect on the composition and/or distribution of REEs in carbonates (limestones and dolomites) except in diagenetic systems with extremely large water/rock ratios (e.g., Banner et al., 1988; Barton et al., 2006; Webb and Kamber, 2000; Kamber and Webb, 2001; Nothdurft et al., 2004; Webb et al., 2009). Despite its general acceptance, there is no consensus among REE workers of this paradigm (e.g., Johannesson and Hawkins, 2006). Webb et al. (2009, p. 1433) based their conclusion on the "... conservative..." behaviour of REEs "...during meteoric diagenesis." However, the presence of occluded aragonite within a calcite matrix, relatively high levels of $\mathrm{Sr}$, low levels of $\mathrm{Mn}$, microstructural ghosts, and ${ }^{87} \mathrm{Srj}{ }^{86} \mathrm{Sr}$ consistent with the age of deposition supports their assertion of neomorphism in an open system of the vadose zone of meteoric water. On the other hand, the application of their conclusion of vadose meteoric water diagenesis to most ancient limestone is inconsistent with diagenetic theory and observations, because most of them altered in closed to open systems (low to high water/rock ratios) in the phreatic-zone meteoric diagenetic microenvironment (e.g, Brand and Veizer, 1980, 1981). Thus, REEs may preserve their apparently 'original' compositions in carbonates stabilized in vadose- controlled diagenetic systems, but the extension of this assumption to all other carbonates altered in phreatic controlled diagenetic systems is not warranted by the evaluation of detailed and coupled diageneticREE results from ancient limestones, dolomites (e.g., Banner et al., 1988; Barton et al., 2006) and cements (Figs. 8 and 10).

The recrystallized lime mudstones (diagenetic phase), including the Ordovician and Silurian materials), with documented considerable alteration of their elemental composition (low Sr contents between 182 and 308 ppm, Azmy et al., 1998, 2008, 2009), have yielded higher mean tREE content $(14.0 \pm 8.7 \mathrm{ppm})$ than those of the modern warm- $(0.3 \pm 0.2 \mathrm{ppm})$ and cold-water $(0.2 \pm 0.2 \mathrm{ppm})$ shells and fossil shells (Table 1 ). The petrographic features of some fabric retention in the lime mudstones and their relatively small crystal size (10-40).Iffi) suggest that diagenetic alterations occurred at early burial stages most likely in the phreatic zone of the meteoric environment (cf.Azmy et al., 2008, 2009).

Recrystallization of carbonates during early diagenesis likely influences the enrichment of the REEs in the diagenetic phase (Table 1), which is similar to the scenario of enrichment of some minor elements (e.g., Mn and Fe) in secondary carbonates (Brand and Veizer, 1980; Veizer, 1983 ). Thus, REEs can be utilized as sensitive indicators of diagenetic redistribution of REE contents in carbonates, in even those altered in a partly closed system diagenetic microenvironment (cf. Silurian lime mudstones; Azmy et al., 1998 ). Similar trends, showing the difference in REE compositions between primary and neomorphic phases, have been documented by other studies on Holocene corals (e.g., Webb et al., 2009). The altered Oligocene brachiopod shells have high tREE and Mn contents and low $\mathrm{Sr}$ contents characteristic of alteration by phreatic meteoric water (Fig. 2; Table 1; Brand and Veizer, 1980).

The deep burial pore- and vein-filling calcite cements (late diagenetic phase) precipitated at higher temperatures $(71-87 \cdot \mathrm{C}$, Azmy et al., 2008) than those involved in the alteration of the enclosing lime mudstones. They have REEs as high as 4 times (45.1 \pm $13.1 \mathrm{ppm}$ ) than tREE contents in the recrystallized lime mudstones (Table 1) and 40 times the contents of the modern shells, which support the argument of REE enrichment in secondary carbonates. However, other burial cements of similar temperatures from the same sedimentary basin (St. George Basin, western Newfoundland in eastern Canada) have significantly lower tREE contents (Fig. 10). This may suggest that the REE enrichment is most likely attributed to REE composition of the diagenetic fluids, and temperature may have had none or an insignificant influence on overall burial calcite cement REE contents.

The diagenetic control on the REE compositions of the recrystallized lime mudstones and burial calcite cements (e.g., Reynard et al., 1999; Feng et al., 2008 ) is also reflected by the considerable correlations $\left(\mathrm{r}^{2}=0.4\right.$ to 0.7$)$ of the $(\mathrm{La} / \mathrm{Sm}) \mathrm{SsN}$ and $(\mathrm{La}, ! \mathrm{Yb}) \mathrm{sN}$ values, but, unlike diagenetic phosphorites (Shields and Stille, 2001), no correlation $(\mathbf{r}<0.01)$ has been found between $(\mathrm{Dy} / \mathrm{Sm}) \mathrm{sN}$ and the $\left(\mathrm{Ce} / \mathrm{Ce}{ }^{*}\right) \mathrm{sN}$ values of the investigated diagenetic carbonates. However, the shale-normalized REE patterns of the altered carbonate phases (lime mudstones and burial calcite cements) have similar 'ghost' profiles that somewhat mimic those of the modern shell bLMC (Fig. 10). The profile of the lime mudstones suggests that diagenetic alterations did not fully reset the precursor REEsN signature (trend) but rather their absolute REE contents. Imitation by the burial calcite cement (diagenetic phase) REE profile of the modern brachiopod REE trend suggests that the parent hydrothermal fluids probably originated from seawater that circulated in the crustal rocks, particularly in the siliciclastics of the St. George Basin (Conliffe et al., 2010). Generally speaking, the enrichment in the LREE is more pronounced than that in the HREE counterparts since the tREE calculations indicate that more than 95\% of the mean tREE values are con tributed by the LREEs, and thus contribute to their 'chevron'-type REESN pattern (Fig. 10). 


\subsection{Secular/extrinsic environmental REE seawater variation}

The REEsN trends of the well-preserved Silurian and Eocene brachiopods are similar to those of their modern counterparts (Fig. 4), but their !REE contents are higher than those of modern brachiopods from open-ocean settings. This is not unexpected because the Silurian brachiopods are from relatively warm waters in an epeiric sea setting, and potentially subject to unusual extrinsic environmental conditions relative to 'normal' open ocean conditions (Fig. 6; Brand et al., 2009). Similarly, the REE contents of the well-preserved Eocene brachiopods are slightly higher than the 'field of REE' for all modern brachiopods tested in this study, which suggests that extraordinary extrinsic environmental conditions may have prevailed during their formational stage (Fig. 6; Peck et al., 2005 ). These differences in the REE contents of the well-preserved Eocene and Silurian brachiopods relative to their modern counterparts, although a limited database, suggest that extrinsic environmental conditions may be responsible for them. Although, secular variation of ancient seawater remains a possibility, and the observation of the Eocene and Silurian bIMC REEsN trends might agree with the current paradigm that pre-Cenozoic seawater had different REE composition, and argue against the conclusions of other studies (e.g., Wright et al., 1984, 1987. These conodont-based studies suggested that the REE composition of seawater has not significantly changed during the Phanerozoic (Wright et al., 1984, 1987; Shields and Webb, 2004). However, preservation of biogenic phosphate has been challenged by a number of studies (e.g., Shields and Webb, 2004; Bright et al., 2009; Kocsis et al., 2010), which seriously opens the static seawater-REE conclusions based on conodont REE contents. In light of only two blMC REE datasets for the geologic past (Eocene and Silurian), we prefer to defer any further and detailed discussion on the potential secular variation of seawater REE content to a future time when more results may be available to us. Absolutely, more analyses of well-preserved brachiopod bLMC from other time periods are required to test this 'open' hypothesis of secular seawater-REE variation (e.g., Picard et al., 2002; Shields and Webb, 2004). This hypothesis and its verification must include specimens (preserved blMC) from epeiric seas as well as ones from open ocean settings (cf. Brand et al., 2009), and from other extrinsic environmental settings to further elucidate its impact on bLMC REEsN contents and trends.

\section{Conclusions}

The incorporation of REE by modern and fossil brachiopod bLMC as well as that by lime mudstone and burial calcite cements suggests some interesting observations about shell deposition, extrinsic environmental influences (water masses) and carbonate diagenesis:

1. Modern brachiopod shells from open-ocean warm- and cold-water settings exhibit insignificant differences in their REE compositions and no vital effect influence. In contrast, modern brachiopods from areas of increased productivity (e.g., upwelling, dust deposition) show enrichments in their REE contents but with REEsN trends similar to those of their 'mainstream' counterparts.

2. Well-preserved Eocene and Silurian brachiopod shells have REEsN trends similar to those of modern brachiopods but with slightly higher contents. Their Ce anomaly values support an oxic surface seawater setting, whereas their REEsN contents suggest blMC deposition in seawater of extraordinary extrinsic environmental conditions.

3. Although, earlier studies suggested a systematic enrichment in REE concentrations in seawater with depth, the REE compositions of modern brachiopod shells from different depths of variable temperatures do not exhibit a significant correlation. Similarly, temperature at most near-surface conditions (warm- and coldwa ter regimes) seems to have an insignificant influence on the fractionation of REEs in primary carbonates (blMC).
4. Carbonate alteration in processes ranging from closed to open systems of phreatic zone, meteoric-water diagenetic microenvironments leads to a positive shift in REEsN trends and enrichment of the individual REE contents in the altered material by about one order of magnitude relative to coeval and preserved bLMC.

5. Burial calcite cements and their host rock, lime mudstones, exhibit more complex diagenetic features related to precipitation of the cements in an open system from burial fluids. Their ultimate REEsN trends exhibit an LREE enrichment coupled by a HREE depletion resembling a 'chevron' shape. Furthermore, analysis of their Ce and La anomaly values suggest calcite cement precipitation in equilibrium with the ambient burial fluid, and its ultimate chemistry (REE and trace element contents) controlled by that of the source fluid.

Supplementary materials related to this article can be found online at doi:10.1016/j.chemgeo.2010.11.007.

\section{Acknowledgement}

We thank Dr. Luke Nothdurft and the anonymous reviewer for their constructive comments of our manuscript, and the editor Dr.J.D. Blum for his patience and encouragement to complete this submission.We thank M. Lozon (Brock University) for drafting of the figures, and this project was funded, in part, by the Natural Sciences and Engineering Research Council of Canada (NSERC) and by Brock and Memorial Universities.

\section{References}

Alibo, D.S., Nozaki, Y., 1999. Rare earth elements in seawater: particle association, shalenormalization, and Ceoxidation. Geochimica et Cosmochimica Acta 63, 363-372. Azmy K., Veizer, J., Bassett, M.G., Copper, P., 1998. Oxygen and carbon isotopic composition of Silurian brachiopods: implications for coeval seawater and glaciations. Geological Society of America Bulletin 110, 1499-1512.

Azmy, K., Lavoie, D., Knight, I., Chi, G., 2008. Dolomitization of the Aguathuna carbonates in western Newfoundland, Canada: implications for a potential hydrocarbon reservoir. canadian Journal of Earth Sciences 45, 795-813.

Azmy, K., Knight, 1., Lavoie, D., Chi, G., 2009. Origin of the Boat Harbour dolomites of St. George Group in western Newfoundland, Canada: implications for porosity controls. Bulletin of Canadian Petroleum Geology 57, 1-24.

Banner, J.L., Hanson, G.N., Meyers, W.J., 1988. Rare earth element and Nd isotopic variations in regionally extensive dolomites from the Burlington-Keokuk Formation (Mississippian): implications for REE mobility during carbonate diagenesis. Journal of Sedimentary Petrology 58, 415-432.

Barrat, J.A., Boulegue, J., Tiercelin, J.J., Lesourd, M., 2000. Strontium isotopes and rareearth element geochemistry of hydrothermal carbonate deposits from Lake Tanganyka, East Africa. Geochimica et Cosmochimica Acta 64, 287-298.

Barton, E.D., Aristegui, J., Tett, P., Navarro-Perez, E., 1998. The transition zone of the Canary Current upwelling region. Progress in Oceanography 41, 455-504.

Barton, E.D., Bau, M., Alexander, B., 2006. Preservation of primary REE patterns without Ce anomaly during dolomitization of Mid-Paleoproterozoic limestone and the potential re-establishment of marine anoxia immediately after the 'Great Oxidation Event'. South African Journal of Geology 109, 81-86.

Bau, M., Dulski, P., 1996. Distribution of yttrium and rare-earth elements in the Penge and Kuruman iron-formations, Transvaal Supergroup, South Africa. Precambrian Research 79,37-55.

Bau, M., Koschinsky, A., Dulski, P., Hein, JR., 1996. Comparison of the partitioning behaviours of yttrium, rare earth elelements, and titanium between hydrogenetic marine ferromanganese crusts and seawater. Geochimica et CosmochimicaActa 60, $1709-1725$.

Brand, U., 2004. carbon, oxygen and strontium isotopes in Paleozoic carbonate components: an evaluation of original seawater -chemistry proxies. Chemical Geology 204, 23-44.

Brand, U., Veizer, ]., 1980. Chemical diagenesis of a multicomponent carbonate system: 1, trace elements. Journal of Sedimentary Petrology 50, 1219-1236.

Brand, U., Veizer, ].,1981. Chemical diagenesis of a multicomponent carbonate system: 2, stable isotopes. Journal of Sedimentary Petrology 51, 987-997.

Brand, U., Logan, A., Hiller, N., Richardson, J., 2003. Geochemistry of modern brachiopods: applications and implications for oceanography and paleoceanography. Chemical Geology 198, 305-334.

Brand, U., Tazawa, J.-1., Sana, H., Azmy, K., Lee, X., 2009. Is mid-late Paleozoic oceanchemistry coupled with epeiric seawater isotope records? Geology 37, 823-826.

Brand, U., Logan, A., Bitner, M.A., Griesshaber, E., Azmy, K., Buhl, D., 2010. Brachiopods: proxies or imposters of seawater chemistry. Geological Society of Australia, Book of Abstracts 95, 20

Bright, C.A, Cruse, A.M., Lyons, T.W., MacLeod, K.G., Glascock, M.D., Ethington, R.L, 2009. Seawater rare-earth element patterns preserved in apatit e of Pennsylvanian conodonts? Geochimica et Cosmochimica Acta 73, 1609-1624. 
Broecker, W.S., Peng, T.-H., 1982. Tracers in the Sea. Lamont-Doherty Geological Observatory. Columbia University, Eldigio Press, Palisades, New York. 690 pp. Came, R.E., Eiler, J.M., Veizer, J., Azmy, K., Brand, U., Weidman, CR., 2007. Coupling of surface temperatures and atmospheric carbon dioxide concentrations during the Palaeozoic Era. Nature 449, 198-201.

Chen, D.F., Dong, W.Q., Qi, L, Chen, G.Q., Chen, X.P., 2003. Possible REE constraints on the depositional and diagenetic environment of Doushantuo Formation phosphorites containing the earliest metazoan fauna. Chemical Geology 201, 103-118.

Coleman, M.L., Walsh, J.N., Benmore, R.A., 1989. Determination of both chemical and stable isotope composition in milligram-size carbonates. Sedimentary Geology 65, 233-238.

Conliffe, J., Azmy, K., Gleeson, S.A., Lavoie, D., 2010. Fluids associated with hydrotherma dolomitization in St. George Group, western Newfoundland, Canada. Geotluids 9 , $1-16$

Copper, P., 1995. Five new genera of Late Ordovician-Early Silurian brachiopods from "Anticosti" Island, Eastern Canada. Journal of Paleontology 69, 846-862.

Copper, P., Brunton, F., 1991. A global review of Silurian reefs. In: Bassett, M.G., Lane, P.O., Edward, D. (Eds.), The Murchison Symposium: Proceedings of an International Conference on the Silurian System. Special Paper, Palaeontology, val. 44 , pp. 225-260.

Elderfield, $\mathrm{H}$. 1988. The oceanic chemistry of the rare-earth elements. Philosophical Transactions of the Royal Society of London 325, 105-126.

Elderfield, H., Hawkesworth, C.J., Greaves, M.J., 1981. Rare earth element geochemistry of oceanic ferromanganese nodules and associated sediments. Geochimica e Cosmochimica Acta 45, 513-528.

Elderfield, H., Upstill-Goddard, R., Sholkovitz, E., 1990. The rare earth elements in rivers, estuaries and coastal sea waters: processes affecting crustal input of elements to the ocean and their significance to the composition of sea water. Geochimica e Cosmochimica Acta 54, 971-991.

Feng, D., Chen, D., Peckmann, J., 2008. Rare earth elements in seep carbonates as tracers of variable redox conditions at ancient hydrocarbon seeps. Terra Nova 21,49-56.

Ferreira, M.M.C., Faria, C.G., Paes, E.T., 1999. Oceanographic characterization of northern Sao Paulo Coastal chemometric study. Chemometrics and Intelligent Laboratory Systems 47, 289-297.

Grandjean, P., Cappetta, H., Michard, A, Albarede, F., 1987. The assessment of REE patterns and ${ }^{143} \mathrm{Nd} /{ }^{144} \mathrm{Nd}$ ratios in fish remains. Earth and Planetary Science Letters 84, 181-196.

Holland, H.D., 1984. The Chemical Evolution of the Amosphere and Oceans. Princeton Series in Geochemistry. Princeton University Press. 582 pp.

Holser, W.T., 1997. Evaluation of the application of rare earth elements to paleoceanography. Palaeogeography, Palaeoclimatology, Palaeoecology 132, 309-323.

Ivany, L.C, Lohman, K.C., Hasiuk, F., Blake, D.B., Glass, A., Aronson, R.B., Moody, R.M 2008. Eocene climate record of high southern latitude continental shelf: Seymour Island, Antarctica. Geological Society of America Bulletin 120, 659-678.

Johannesson, K.H., Hawkins, D.L.J., 2006. Do Archean chemical sediments record ancient seawater rare earth element patterns? Geochimica et Cosmochimica Acta 70 871-890.

Kamber, B.S., Webb, G.E., 2001. The geochemistry of late Archean microbial carbonate: implications for ocean chemistry and continental erosion history. Geochimica et Cosmochimica Acta 65, 2509-2525.

Kocsis L, Trueman, CN., Palmer, M.R., 2010. Protracted diagenetic alteration of REE contents in fossil bioapatites: direct evidence from Lu-Hf isotope systematic. Geochimica et Cosmochimica Acta 74, 6077-6092.

Lecuyer, C., Reynard, B., Grandjean, P., 2004. Rare earth element evolution of Phanerozoic seawater recorded in biogenic apatites. Chemical Geology 204, 63-102.

Lee, J.H., Byrne, R.H., 1993. Complexation of trivalent rare earth elements (Ce, Eu, Gd, Tb, Yb) by carbonate ions. Geochimica et Cosmochimica Acta 57, 295-302.

McArthur, J.M., Walsh, J.N., 1984. Rare-earth geochemistry of phosphorites. Chemical Geology 47, 91-220.

McLennan, S.M., 1989. Rare earth elements in sedimentary rocks: influence of provenance and sedimentary processes. In: Lipin, B.R., McKay, G.A (Eds.), Geochemistry and Mineralogy of Rare Earth Elements: Mineral. Soc. Am. Rev. Miner., vol. 21, pp. 169-200.
Murray, R.W., Buchholtz ten Brink, M.R., Gerlach, D.C., Russ, G.R.l., Jones, D.L, 1992. Interoceanic variation in the rare earth, major, and trace element depositional chemistry of chert: perspectives gained from DSDP and ODP records. Geochimica et Cosmochimica Acta 56, 1897-1913.

Negrel, P., Casanova, J., Brulhet, J., 2006. REE and Nd isotope stratigraphy of a Late Jurassic carbonate platform, eastern Paris Basin, France. Journal of Sedimentary Research 76, 605-617.

Nothdurft, LD., Webb, G.E., Kamber, B.S., 2004. Rare earth element geochemistry of Late Devonian reefal carbonates, Canning Basin, Western Australia: confirmation of a seawater REE proxy in ancient limestones. Geochimica et Cosmochimica Acta 68, 263-283.

Palmer, M.R., 1985. Rare earth elements in foraminifera tests. Earth and Planetary Science Letters 73, 285-298.

Peck, LS., Barnes, D.K.A., Willmott, J., 2005. Responses to extreme seasonality in food supply: diet plasticity in Antarctic brachiopods. Marine Biology 147, 453-463.

Picard, S., Lecuyer, C, Barrat,J.-A., Garcia, J.-P., Dromart, G., Sheppard, S.M.F., 2002. Rareearth element contents of Jurassic fish and reptile teeth and their potential relation to seawater composition (Anglo-Paris Basin, France and England). Chemical Geology 186, 1-16.

Reynard, B., Lecuyer, C., Grandjean, P., 1999. Crystal-chemical controls on rare-earth element concentrations in fossil biogenic apatites and implications for paleoenvironmental reconstructions. Chemical Geology 155, 233-241.

Scherer, M., Seitz, H., 1980. Rare earth element distribution in Holocene and Pleistocene corals and their redistribution during diagenesis. Chemical Geology 28, 279-289.

Shaw, H.F., Wasserburg, G.J., 1985. Sm-Nd in marine carbonates and phosphates: implications for $\mathrm{Nd}$ isotopes in seawater and crustal ages. Geochimica et Cosmochimica Acta 49, 503-518.

Shen, G.T., Sanford, C.L., 1989. Trace element indicators of climate variability in reebuilding corals. Global Ecological consequences of the 1982-1983 El NinoSouthern Oscillation. Elsvier, pp. 255-283.

Shields, G., Stille, P., 2001. Diagenetic constraints on the use of cerium anomalies as palaeoseawater redox proxies: an isotopic and REE study of Cambrian phosphorites. Chemical Geology 175, 29-48

Shields, G.A., Webb, G.E., 2004. Has the REE composition of seawater changed over geological time? Chemical Geology 204, 103-107.

Sholkovitz, E., Shen, G.T., 1995. The incorporation of rare-earth elements in modern coral. Geochimica et Cosmochimica Acta 59, 2749-2756.

Sholkovitz, E., Landing, W.M., Lewis, B.L., 1994. Ocean particle chemistry: the fractionation of rare earth elements between suspended particles and seawater. Geochimica et CosmochimicaActa 58, 1576-1580.

Veizer, J., 1983. Chemical diagenesis of carbonates: theory and application of trace element technique. In: Arthur, M.A., Anderson, T.F., Kaplan, I.R., Veizer, J., Land, L.S. (Eds.), Stable Isotopes in Sedimentary Geology: Society of Economic Paleontologists and Mineralogists Short Course Notes, 10, pp. III-1-III-100.

Webb, G.E., Kamber, B.S., 2000. Rare earth elements in Holocene reefal microbialites: a new shallow seawater proxy. Geochimica et CosmochimicaActa 64, 1557-1565.

Webb, G.E., Nothdurft, L.D., Kamber, B.S., Kloprogge, J.T., Zhao, J.-X., 2009. Rare earth element geochemistry of scleractinian coral skeleton during meteoric diagenesis: a before and-after sequence through neomorphism of aragonite to calcite. Sedimentology 56, 1433-1463.

Wright, Judith, Seymour, Richard S., Shaw, Henry F., 1984. REE and Nd isotopes in conodont apatite: variations with geological age and depositional environment. In: Oark, L (Ed.), Conodont Biofacies and Provincialism.: Sp. Pap., vol. 196. Geological Society of America, Boulder, pp.325-340.

Wright, J, Schrader, H., Holser, W.T, 1987. Paleoredox variations in ancient oceans recorded by rare earth elements in fossil apatite. Geochimica et Cosmochimica Acta 51, 631-644.

Zhang, J., Nozaki, Y., 1996. Rare earth elements and yttrium in seawater: ICP MS determinations in the East Caroline, Coral Sea, and South Fiji basins of the western South Pacific Ocean. Geochimica et Cosmochimica Acta 60, 4631-4644.

Zhong, S., Mucci, A., 1995. Partitioning of rare earth elements (REEs) between calcite and seawater solutions at $25^{\circ} \mathrm{C}$ and $1 \mathrm{~atm}$, and high dissolved REE concentrations. Geochimica et Cosmochimica Acta 59, 443-453. 